7 - ORIGINAL ARTICLE

ISCHEMIA/REPERFUSION

\title{
Biochemical study of the effects of cilostazol in rats subjected to acute ischemia and reperfusion of hind limbs ${ }^{1}$
}

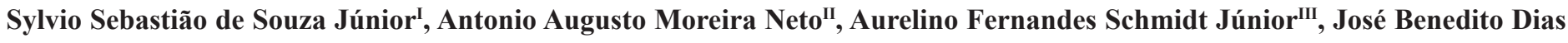 \\ Lemos $^{\mathrm{IV}}$, Olavo Ribeiro Rodrigues ${ }^{\mathrm{V}}$ \\ ${ }^{\mathrm{I}}$ Fellow PhD degree, Postgraduate Program in Biomedical Engineering, UMC, Mogi das Cruzes-SP, Brazil. Main author. Conception, design, intellectual \\ and scientific content of the study. \\ IIPhD, Assistant Professor, Department of Surgery, Vascular Surgery Division, UMC, Mogi das Cruzes-SP, Brazil. Involved with technical procedures, \\ acquisition of data and critical revision. \\ IIIPhD, Assistant Professor, Department of Surgery, Thoracic Surgery Division, UMC, Mogi das Cruzes-SP, Brazil. Critical revision. \\ ${ }^{\text {IV }} \mathrm{PhD}$, Assistant Professor, Department of Surgery and Traumatology, Surgical Techniques and Experimental Surgery Division, Sao Paulo University \\ (USP), Sao Paulo-SP, Brazil. Critical revision. \\ ${ }^{\mathrm{v}} \mathrm{PhD}$, Assistant Professor, Postgraduate Program in Biomedical Engineering, UMC, Mogi das Cruzes-SP, Brazil. Conception and design of the study, \\ critical revision.
}

\begin{abstract}
PURPOSE: To investigate whether cilostazol has a protective effect on acute ischemia and reperfusion of hind limbs of rats through study of biochemical variables in blood and urine.

METHODS: Forty six animals were randomized and divided into two groups. Group I received a solution of cilostazol (10 mg/Kg) and group II received saline solution $0.9 \%$ (SS) by orogastric tube after ligature of the abdominal aorta. After four hours of ischemia the animals were divided into four subgroups: group IA (Cilostazol): two hours of reperfusion. Group IIA (SS): two hours of reperfusion. Group IB (Cilostazol): six hours of reperfusion. Group IIB (SS) six hours of reperfusion. After the reperfusion period, was held to collect urine and blood for biochemical measurements. The biochemical parameters studied were: urea, creatinine, sodium, potassium and myoglobin in blood and urea, creatinine, myoglobin in urine.
\end{abstract}

RESULTS: There was no statistically significant difference between groups.

CONCLUSION: Cilostazol had no protective effect on ischemic acute reperfusion of hind limbs of rats in this model.

Key words: Ischemia. Reperfusion. Urea. Creatinine. Myoglobin. Rats. 


\section{Introduction}

The reperfusion syndrome is characterized by metabolic acidosis, hyperkalemia by the loss of intracellular potassium, increased serum creatine kinase and myoglobin with myoglobinury ${ }^{1}$. May result in acute renal failure: coagulation disorders, accumulation of extracellular fluid and acute pulmonary distress $^{2}$.

With the acute ischemia, initiating anaerobic metabolism, glycogen with transformation into lactate, leading to decreased production of adenosine triphosphate (ATP), which alters the permeability of the cell muscle, allowing the output of potassium and myoglobin and entry Sodium and calcium célula ${ }^{3}$.

The cell damage occurs only after an interval of thirty minutes of ischemia and irreversible changes in skeletal muscle occur after four to six hours of ischemia. Ischemia can lead to cell death by necrosis or apoptosis ${ }^{4}$.

After reperfusion muscle, is released into the circulation of acid metabolites and products of cell destruction that cause significant metabolic alterations, such as metabolic acidosis and hyperkalemia ${ }^{5}$. The more severe change is due to precipitation of myoglobin in the renal tubules in acid environment, causing acute tubular necrosis ${ }^{6}$.

Treatment of acute ischemia reperfusion is only the affected territory reperfusion of which may lead to ischemia and reperfusion syndrome.

Many times reperfusion cannot be performed immediately after the onset of ischemia, since there is a very variable period of time between the first symptoms of the disease and emergency medical care.

Cilostazol is an antiplatet drug and vasodilator with antimitogenics and cardiotonic actions ${ }^{7}$ intended to reduce the symptoms of peripheral vascular disease, intermittent claudication ${ }^{8}$ and prevention of recurrent cerebral stroke 9 .

We hypothesize that cilostazol inhibits platelet aggregation and promoting vasodilation could decrease the deleterious effects of ischemia and reperfusion syndrome. If administered at the onset of ischemia could reduce acute ischemic events, and consequently reduce renal injury after reperfusion.

The objective of this study is to assess the effect of cilostazol in rats submitted to acute ischemia and reperfusion of hind limbs through study of biochemical variables in blood and urine, since no experimental models in animals studies on the effectiveness of cilostazol in acute ischemia and reperfusion have been reported.

\section{Methods}

This study was approved by the Ethics Committee for Animal Experimentation and Manipulation (CEMEA) on 10.03.2008 and according to Federal Law No. 11.794, of October 8, 2008, and Decree No. 6689 of July 15, 2009 which regulated Law 11,794.

The experiment was developed at the Center for Technological Research (NPT) of Mogi das Cruzes University in the period from July/2008 to October /2010.

Forty six male Wistar rats, ten months age and average weight of 300 grams were used.

\section{Surgical technique}

The animals were anesthetized and placed an orogastric tube.

Laparotomy was performed in $4 \mathrm{~cm}$ long. The abdominal aorta was ligated just below the renal artery with propylene $7.0^{10}$. Proceeded to divided into two randomly groups:

Group I (Cilostazol) - 24 animals, received by the tube solution of cilostazol (Cebralat ${ }^{\circledR}$, Libbs) at a concentration of $1 \mathrm{mg}$ $/ \mathrm{ml}$ in $10 \mathrm{mg} / \mathrm{kg}$.

Group II (Sham) - 22 animals: received $10 \mathrm{ml} / \mathrm{kg}$ saline solution $0.9 \%$.

The solutions were administered immediately after aortic ligature.

The effectiveness of aortic ligature was confirmed by the appearance of pallor, cyanosis and decreased temperature on their hind legs for thermometry. The absence of pulse and flow in the aorta below the ligature was confirmed by intraoperative Dopplermetry.

\section{Ischemic time}

After aortic ligature, started to measure ischemia time and proceeded to the closure of the laparotomy.

After four hours of ischemia relaparotomy was performed in order to remove the aortic ligature and then, closed.

\section{Reperfusion time}

After removing aortic ligature, started to measure time of reperfusion.

Two animals were excluded from the previous steps of the experiment because they died before the final reperfusion time. 
Forty-four animals underwent a second phase, remaining in the study.

Proceeded to the distribution of animals in four groups according to the time of reperfusion:

Group IA: 13 animals that received cilostazol with reperfusion time of two hours.

Group IIA: 12 animals receiving saline solution $0.9 \%$, with time of two hours of reperfusion.

Group IB: ten animals receiving cilostazol with reperfusion time of six hours.

Group IIB: nine animals receiving saline solution 0.9\%, with time of six hours of reperfusion.

\section{Collection of blood and urine and euthanasia}

Again the animals were anesthetized and proceeded to puncture the bladder and completing cardiac puncture euthanasia.

The secret allocation was obeyed.

For biochemical analysis were measured to mioglobulina, urea and creatinine, sodium and potassium in the blood and mioglobulina, urea and creatinine in urine.

When the sample showed a normal distribution, shown by the normality of Shapiro-Wilk test was used t Test for sample data from two independent samples, with $\mathrm{p} \leq$ to 0.05 for significance. When the sample did not show a normal distribution, we used nonparametric test for two independent samples, Mann-Whitney (Wilcoxon rank-sum test), with $\mathrm{p} \leq$ to 0.05 for significance.

\section{Results}

The biochemical parameters studied, both in blood and in urine were not statistically significant change compared between groups with two to six hours of reperfusion, animals treated with cilostazol or not (Tables 1, 2 and 3).
TABLE 1 - Results of the biochemical parameters in the blood of animals in groups with two hours of reperfusion.

\begin{tabular}{|c|c|c|c|c|c|}
\hline Animal & $\begin{array}{l}\text { Urea } \\
\mathrm{mg} / \mathrm{dL}\end{array}$ & $\begin{array}{c}\text { Creatinine } \\
\mathrm{mg} / \mathrm{dL}\end{array}$ & $\mathrm{Na}+\mathrm{mEq} / \mathrm{L}$ & $\mathrm{K}+\mathrm{mEq} / \mathrm{L}$ & $\begin{array}{c}\text { Myoglobin } \\
\text { mcg/L }\end{array}$ \\
\hline \multicolumn{6}{|c|}{ Group IA } \\
\hline 1 & 92 & 1.3 & 132 & - & - \\
\hline 3 & 107 & 0.5 & 139 & 6.5 & 92.2 \\
\hline 12 & 55 & 0.3 & 138 & 4.3 & 283 \\
\hline 14 & 69 & 0.4 & 135 & 5.1 & 219 \\
\hline 17 & 66 & 0.2 & 135 & 6.4 & 309 \\
\hline 19 & 71 & 0.4 & 135 & 6 & 262 \\
\hline 30 & 63 & 0.3 & 136 & 5.4 & 619 \\
\hline 31 & 77 & 0.4 & 136 & 5.1 & 208 \\
\hline 32 & 96 & 0.7 & 136 & 5.8 & 302 \\
\hline 35 & 83 & 0.6 & 136 & 5.3 & 454 \\
\hline 36 & 80 & 0.3 & 137 & 5.1 & 235 \\
\hline 45 & 52 & 0.2 & 138 & 4.6 & 96 \\
\hline 47 & 49 & 0.3 & 136 & 4.9 & - \\
\hline Median & 73.8461 & 0.4538 & 136.0769 & 5.3751 & 279.9273 \\
\hline
\end{tabular}

\begin{tabular}{|c|c|c|c|c|c|}
\hline \multicolumn{6}{|c|}{ Group IIA } \\
\hline 4 & 72 & 0.4 & 142 & 6.6 & 42.5 \\
\hline 15 & 61 & 0.4 & 138 & 4.7 & 303 \\
\hline 16 & 89 & 0.3 & 137 & 4.9 & 145 \\
\hline 18 & 59 & 0.2 & 137 & 5.6 & 165 \\
\hline 33 & 73 & 0.3 & 138 & 4.7 & 208 \\
\hline 34 & 64 & 0.5 & 136 & 5.2 & 391 \\
\hline 42 & 49 & 0.3 & 136 & 5 & 171 \\
\hline 43 & 69 & 0.3 & 138 & 4.5 & 164 \\
\hline 44 & 64 & 0.2 & 135 & 5.7 & 224 \\
\hline 46 & 45 & 0.2 & 138 & 4.6 & 182 \\
\hline 48 & 67 & 0.3 & 134 & 5.2 & 152 \\
\hline 49 & 67 & 0.3 & 134 & 4.7 & 47 \\
\hline Median & 64.9167 & 0.3083 & 136.9167 & 5.1167 & 182.8751 \\
\hline $\mathrm{t}$ Test & 0.149 & - & 0.3 & 0.336 & 0.077 \\
\hline $\begin{array}{l}\text { Mann- } \\
\text { Whitney }\end{array}$ & - & 0.141 & - & - & - \\
\hline
\end{tabular}


TABLE 2 - Results of the biochemical parameters in urine of the animals in groups with two hours of reperfusion.

\begin{tabular}{|c|c|c|}
\hline Animal & $\begin{array}{c}\text { Myoglobin } \\
\text { mcg/L }\end{array}$ & $\begin{array}{c}\text { Creatinine (uro) } \\
\mathrm{mg} / \mathrm{dL}\end{array}$ \\
\hline \multicolumn{3}{|c|}{ Group IA } \\
\hline 1 & - & - \\
\hline 3 & 27 & - \\
\hline 12 & 1840 & 88 \\
\hline 14 & 1440 & 63.5 \\
\hline 17 & 71 & 99.25 \\
\hline 19 & 64 & 72.25 \\
\hline 30 & 1940 & 33.5 \\
\hline 31 & - & 87.5 \\
\hline 32 & 329 & 45.25 \\
\hline 35 & - & 24.75 \\
\hline 36 & 6520 & 59.75 \\
\hline 45 & - & 75 \\
\hline 47 & - & 36.25 \\
\hline Median & 1528.88 & 62.2727 \\
\hline \multicolumn{3}{|c|}{ Group IIA } \\
\hline 4 & 214 & - \\
\hline 15 & 1620 & 70 \\
\hline 16 & 55 & - \\
\hline 18 & 150 & 73.25 \\
\hline 33 & 2010 & 104.25 \\
\hline 34 & 6380 & 66.65 \\
\hline 42 & - & - \\
\hline 43 & - & 62.25 \\
\hline 44 & 81 & 94 \\
\hline 46 & 396 & 42.5 \\
\hline 48 & 255 & 43.75 \\
\hline 49 & - & 123.75 \\
\hline Median & 1240.1111 & 75.6 \\
\hline $\mathrm{t}$ Test & & 0.266 \\
\hline $\begin{array}{l}\text { Mann- } \\
\text { Whitney }\end{array}$ & 0.962 & \\
\hline
\end{tabular}

TABLE 3 - Results of the biochemical parameters in the blood of animals in groups of six hours of reperfusion.

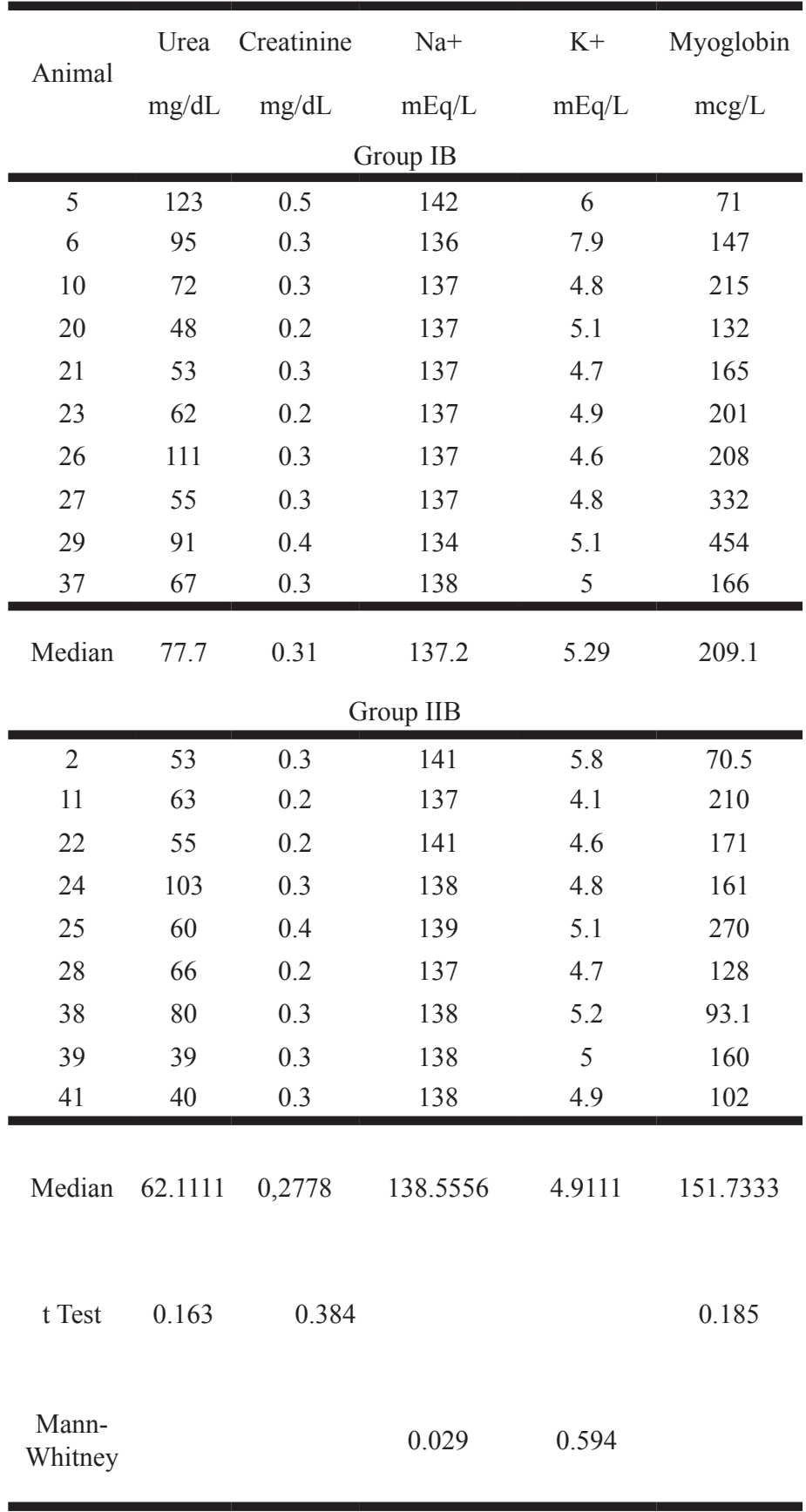

\section{Discussion}

The cilostazol has been widely used in the treatment of chronic peripheral arterial disease and in treatment of ischemic coronary artery disease due to its antiplatelet and vasodilatation properties ${ }^{7}$.

The therapeutic use of cilostazol in acute ischemia and its role in prevention of reperfusion syndrome has not been 
Biochemical study of the effects of cilostazol in rats subjected to acute ischemia and reperfusion of hind limbs

recommended. The lack of randomized controlled studies, using cilostazol in ischemia and reperfusion in rat kidney and muscle, we have motivated the design of this research. In this study it was hypothesized that cilostazol might have efficacy in treating acute ischemia and would decrease the metabolic syndrome of reperfusion protects target organs such as muscle and kidney.

Experimental studies have demonstrated that cilostazol obtained a protective effect against ischemic injury in animal models when used in another organs than skeletal muscle and kidneys $^{11,12}$.

Several experimental studies had model and design similar to our study to investigate the effectiveness of other drugs in ischemia and reperfusion ${ }^{6,14,15}$

An experimental study demonstrated that cilostazol reduces the oxidative stress of ischemia and reperfusion in rats subjected to 45 minutes of spinal cord ischemia by clamping the aorta and a reperfusion period of 48 hours. The biochemical and histopathological analysis of the treated animals at a dose of cilostazol $20 \mathrm{mg} / \mathrm{kg}$ orally for three days before spinal cord ischemia, demonstrated a reduction in neurological damage and a reduction of oxidative stress ${ }^{16}$.

The tissue injury caused by ischemia and reperfusion is described as early onset, and studies have shown that biochemical changes are observable after four hours of ischemia and 15 minutes of reperfusion ${ }^{13}$.

In this study, biochemical changes due to ischemia and reperfusion were observed in the blood in similar intensity in the animals receiving cilostazol and those who received only saline solution. These changes were independent of reperfusion time, since it did not differ significantly in the two groups and underwent six hours of reperfusion.

This may be due to the number of subjects used, which the analysis of a few animals per group, had no power to find statistically significant differences.

It was not possible to study the urinary levels of myoglobin and creatinine in groups of six hours of reperfusion due to insufficient amount of urine in the bladder of the animal at the time of collection.

\section{Conclusion}

Cilostazol had no protective effect on the kidney and the skeletal striated muscle in rats submitted to acute ischemia and reperfusion in this model.

\section{References}

1. Haimovici H. Peripheral arterial embolism. A study of 330 unselected cases of embolism to the extremities. Agiology. 1950;1:1-20.

2. Blaisdell FW. The reperfusion syndrome. Microcirc Endothelium Lymphatics. 1989;5(3-5):127-41.

3. Silveira M, Yoshida SB. Isquemia e reperfusão em músculo esquelético. J Vasc Br. 2004;3(4):367-78.

4. Badhwar A, Dungey AA, Harris KA. Limitations of ischemic tolerance in oxidative skeletal muscle: perfusion vs tissue protection. J Surg Res. 2003;109:62-7.

5. Lockshin RA. An attempt to understand the multiparametric control of the initiation of apoptosis. Apoptosis. 2008;13(1):1195-97.

6. Teruya R, Fagundes DJ, Oshima CTF, Brasileiro JL, Marks G, Ynouye CM, Simões MJ. The effects of pentoxifylline into the kidneys of rats in a model of unilateral hindlimb ischemia/ reperfusion injury. Acta Cir Bras. 2008;23(1):29-35.

7. Akiyama H, Kudo S, Shimizu T. The absorption, distribution and excretion of a new antithrombotic and vasodilating agent, cilostazol, in rat, rabbit, dog and man. Arzneimittelforschung 1985;35(7A):1124-32.

8. Rowlands TE, Donnelly R. Medical therapy for intermittent claudication. Eur J Vasc Endovasc Surg. 2007;34(3):314-21.

9. Huang Y, Cheng Y, Wu J, Li Y, Xu E, Hong Z. Cilostazol as an alternative to aspirin after ischaemic stroke: a randomised, doubleblind, pilot study. Lancet Neurol. 2008;7(6):494-9.

10. Francisco Neto A, Silva JCCB, Fagundes DJ, Percário S, Novo NF, Juliano Y, Moreira Neto AA. Estudo das alterações oxidativas, da capacidade antioxidante total e do óxido nítrico, em ratos submetidos à isquemia e reperfusão de membros posteriores. Acta Cir Bras. 2005;20(2):134-39.

11. Fukusawa $M$, Nishida $H$, Sato $T$, Miyazaki $M$, Nakaya $H$. [4-(1-Cyclohexyl-1H-tetrazol-5-yl)butoxy]-3,4-dihydro-2-(1H) quinolinone (cilostazol), a phosphodiesterase type 3 inhibitor, reduces infarct size via activation of mitochondrial $\mathrm{Ca} 2+-$ activated $\mathrm{K}+$ channels in rabbit hearts. J Pharmacol Exp Ther. 2008;326(1):100-4.

12. Lee JH, Park SY, Shin YW, Hong KW, Kim CD, Sung SM, Kim KY, Lee WS. Neuroprotection by cilostazol, a phosphodiesterase type 3 inhibitor, against apoptotic white matter changes in rat after chronic cerebral hypoperfusion. Brain Res. 2006;1082(1):182-91.

13. Iba T; Kidokoro A; Fukunaga M; Takuhiro K; Ouchi M; Ito Y. Comparison of the protective effects of type III phosphodiesterase (PDE3) inhibitor (cilostazol) and acetylsalicylic acid on intestinal microcirculation after ischemia reperfusion injury in mice. Shock. 2006;26(5):522-6

14. Brasileiro JL, Fagundes DJ, Miiji LON, Oshima CTF, Teruya R, Marks G, Inouye CM, Santos MA. Isquemia e reperfusão de músculo sóleo de ratos sob ação da pentoxifilina. J Vasc Bras. 2007;6(1):5063.

15. Francischetti I, Maffei FHA, Bitu-Moreno J, Fuhrmann Neto M, Coelho MPV, Kai FHT, Sequeira JL, Yoshida WB. Ação do ácido trissódio-cálcio-dietileno-triaminopentaacético (CaNa3DTPA) nas lesões de isquemia-reperfusão em membro posterior de rato. Acta Cir Bras. 2002;17(5):332-41.

16. Sahin MA, Onan B, Guler A, Oztas E, Uysal B, Arslan S, Demirkilic U, Tatar H. Cilostazol, a type III phosphodiesterase inhibitor, reduces ischemia/reperfusion-induced spinal cord injury. Heart Surg Forum. 2011;14(3):E171-7. 


\section{Correspondence:}

Sylvio Sebastião de Souza Junior

Rua Barão de Jaceguai, 509/sala 61

08710-160 Mogi das Cruzes - SP Brasil

Tel.: (55 11)4726-3718

sylvio.vascular@uol.com.br

Received: January 16, 2013

Review: March 18, 2013

Accepted: April 17, 2013

Conflict of interest: none

Financial source: none

${ }^{1}$ Research performed at Center for Technological Research (NPT), Mogi das Cruzes University (UMC), Sao Paulo, Brazil. 